\title{
The Effects of Family Ownership, Earnings Management and Ethnic Diversity For Firm Value
}

\author{
Siti Masulah* \\ Economics and Business Department, Airlangga University, Indonesia
}

\begin{abstract}
This research aims to find out the relationship of family ownership, earnings management and ethnic diversity for firm value. The dependent variable used in this study is company value while the independent variables used are family ownership, earnings management and ethnic diversity. Other than that, this study also uses control variables. The control variables used are company size, company age, leverage and profitability. The population used in this study is mining companies listed on the Indonesia Stock Exchange in 2012-2017. The sampling method used is saturated sampling. The type of data used is secondary data obtained from the company's financial statements and annual reports. The results showed that family ownership, earnings management ethnic diversity, company size, company age and leverage do not effect on firm value, while profitability have a positive effect on firm value.
\end{abstract}

Keywords: family ownership, earnings management, ethnic diversity, firm value

DOI: $10.7176 /$ RJFA/10-18-02

Publication date:September $30^{\text {th }} 2019$

\section{Introduction}

In the current era of globalization, many companies are competing with each other to become competent companies among other companies. One reflection of a competent company is having high company value. Nurhayati (2013) said that high firm value is the desire of every company owner. This is caused the high company value showing the prosperity of the company owner is also high. In order to increase the value of the company, it is important to explore the factors that can affect the value of the company. There are several factors that can increase firm value, including family ownership, earnings management and ethnic diversity.

Badrul Muttakin et al. (2014); Juniarti (2015); L. Kalyanaraman (2015); Klein et al. (2005); Shyu (2011) researching about family ownership and firm value. Juniarti (2015); Klein et al. (2005) said that family ownership negatively influences company value. While Badrul Muttakin et al. (2014); L. Kalyanaraman (2015); Shyu (2011) says that family ownership has a positive effect on family ownership.

Foerster et al. (2009); Helmayunita and Sari (2013); Herman and Purwanto (2014); Suffian et al. (2015); Tandry et al. (2014); Yorke et al. (2016) researching about the relationship between earnings management and firm value. Foerster et al. (2009); Herman and Purwanto (2014); Suffian et al. (2015); Tandry et al. (2014) said that earnings management has a positive effect on firm value. The opposite Helmayunita and Sari (2013) and Yorke et al. (2016) said that earnings management has a negative effect on firm value.

Gul and Zhang (2016); Gyapong et al. (2016); Jean et al. (2011) did research on the relationship between ethnic diversity and firm value. The results of the research of Gyapong et al. (2016) said that ethnic diversity has a positive effect on firm value. Gul and Zhang (2016) state that ethnic diversity has a negative effect on firm value while the results of the study of Jean et al. (2011) said that ethnic diversity has no influence on firm value.

The research was done in the mining sector, the reason for choosing a mining sector company is because oil and coal production from 2012-2015 has decreased, while petroleum and coal are commodities from the mining sector. When oil and coal production has decreased, it will affect the stock price. When stock prices are low, investors tend to be reluctant to invest in companies so that it will cause a decrease in the value of a company.

The following table will present the 2012-2015 crude oil and coal production charts and graphs for the 20122015 mining sector stock price movements:

Table 1. Crude Oil and coal Production in 2012-2015

\begin{tabular}{llll}
\hline No & Tahun & Cruid Oil And Consedates (000 barrel) & Coal \\
\hline 1 & 2012 & $314.665,90$ & 466.307 .241 \\
\hline 2 & 2013 & $301.191,90$ & 458.462 .513 \\
\hline 3 & 2014 & $287.902,20$ & 435.742 .874 \\
\hline 4 & 2015 & $286.814,90$ & 405.871 .432 \\
\hline
\end{tabular}




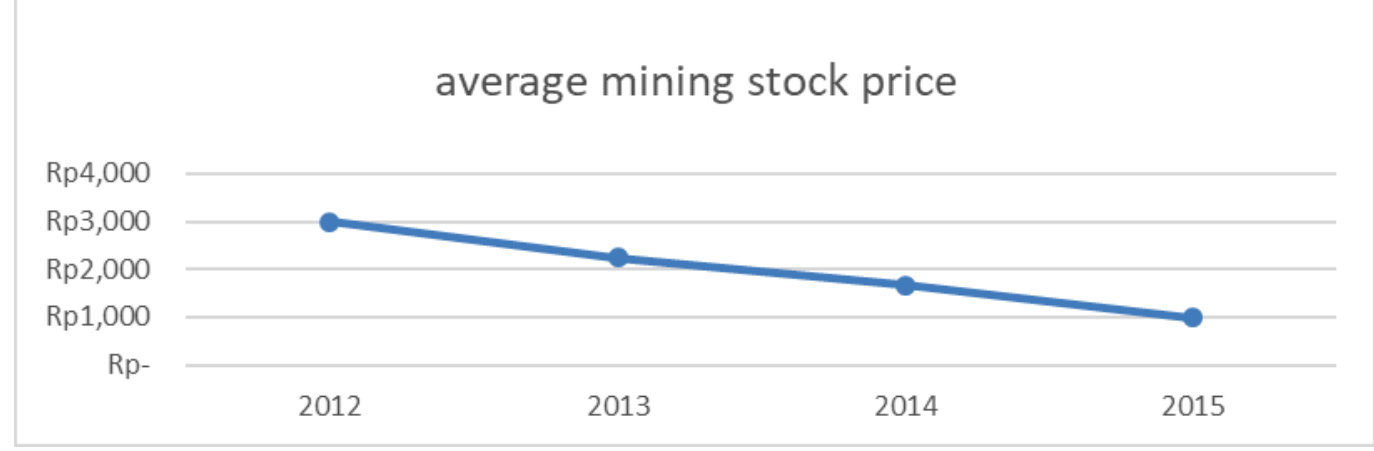

Figure 1. Chart of Mining Sector Stock Price Movement in 2012-2015

The purpose of this research is to prove empirically the relationship of family ownership, earnings management and ethnic diversity on firm value.

Based on the results of research that has not been consistent and the phenomena that have occurred. Then it can be possible to conduct research on the influence of family ownership, earnings management and ethnic diversity on firm value.

The object of research used in this research is mining companies listed on the Indonesia Stock Exchange in 2012-2017. The number of samples used in this research amounted to 154 by using saturated sampling in the form of sampling techniques.

The results showed that family ownership, earnings management and ethnic diversity have no effect on firm value. While the control variables in this research are company size, company age and leverage do not affect to firm value but profitability has a positive effect on firm value.

In the next section, this research will discuss about the literature review and hypothesis, research design, research results and conclusions from this research.

\section{Literature Review}

\subsection{Agency Theory}

Jensen and Meckling (1976) define the agency relationship as a contract where one or more people (principal) involve another person (agent) to do some work on their behalf and delegate some decision-making authority to the agent.

Agency theory express that a person is ultimately selfish, they have a conflict of interest on several issues, they will try to get involved in cooperative efforts. This cooperation not only includes trade through partnerships and companies, but also through interactions within families and other social organizations (Jensen, 1994).

\subsection{Firm Value}

Firm value is referred to as an increase in market prices or stock prices and an increase in company sales (Balakrishnan and Radha, 2016). According to Mahpudin (2016) the value of the company is referred to as the market value of the company because the value of the company provides prosperity to shareholders to the maximum if the stock price increases. The higher the stock price, the higher the prosperity of the shareholders

\subsection{Family Ownership}

Family ownership can be said to be superior than non-family businesses. There are two reasons why family ownership is superior than non-family businesses. The first reason, management in a family company makes better investment decisions, because the family manager has more specific knowledge of the company being managed and has a good idea for long-term investment. The second reason, family management can reduce the main problem known as agency problems. Reducing agency problems can help in adjusting management incentives to the expectations of shareholders (F. Abdullah et al., 2011). Shyu (2011) said that family companies treat companies not as part of their wealth but as assets for their offspring.

\subsection{Earnings Management}

Earnings management is described as a itentional action by managers to manipulate accounting numbers. The purpose of earnings management is to illustrate that financial statements are in a good position to retain existing shareholders and to attract shareholders to invest in the company (Suffian et al., 2015). Earnings management is often seen as a strategy used by company management to manipulate company profits, either to meet predetermined targets or to manage opportunistically income (Madhogarhia et al., 2009). 


\subsection{Ethnic Diversity}

Ethnic diversity is related with probability that there are two individuals chosen at random in a community group from different ethnic groups (Awaworyi Churchill et al., 2017). Shukeri et al. (2012) said an organization with a high level of heterogeneity in management can provide a better final decision. This is based on a variety of more critical thinking so that it can improve management performance.

\subsection{Hypothesis Development}

\subsubsection{Effect Of Family Ownership On Firm Value}

Agency theory said the companies that owned by family have a trusting relationship between family members so that they can reduce monitoring costs. Because every family member have the same goal, which is to maximize family wealth. In the other that, agency theory also said that family ownership can help to reduce conflicts of interest between controlling shareholders and non-family professional managers (H. M. Chung and Chan, 2012). When family ownership in a company increases, the value of the company will increase. This is due to the large family ownership that can minimize agency problems. The thing that benefits from reducing agency problems is reducing agency costs. When agency costs are low, the firm's value will increase. Based on the description, the research hypothesis is:

H1 family ownership positive effect on firm value.

\subsubsection{Effect Of Erning Management On Firm Value}

According to De Jong et al. (2014) the purpose of managers were doing earnings management is to improve investor valuations of their companies. De Jong et al. (2014) also mentioned that earnings management actions can destroy the value of the company in the long way.

Agency theory become between shareholders and managers. Managers try to minimize company income to maximize personal profit (Suffian et al., 2015). The manager must maximize shareholder value gains so that shareholders get return from their investments. But managers have goals for personal gain. So from the differences in interests between managers and shareholders appear the importance conflict.

Based on the description, the research hypothesis is:

$\mathrm{H} 2$ : Earnings management negatively effects on firm value.

2.6.3. Effect Of Ethnic Diversity On firm value

Theories and evidence show that ethnic diversity can affect to firm value. if the board of directors who have different ethnic backgrounds allows the company to have a collection of ideas, more experience and can provide access to new markets (Nathan, 2016). Therefore, the higher the ethnic diversity in a company, the value of the company tends to increase. This is because the high ethnic diversity can expand the market network so as to increase sales. Based on the explanation above, the research hypothesis is:

H3: Ethnic diversity has a positive effect on firm value

\section{Research Methodes}

\subsection{Research Variable}

\subsubsection{Dependent Variable}

The dependent variable used in this research is firm value. Firm value is defined as the market value of the company divided by the cost of replacing capital. Firm value is measured using tobin's Q. The following formula for calculating tobin's Q;

$$
\text { Tobin's } Q=\frac{M V E+D e b t}{T A}
$$

Information:

Tobin's Q: Firm value

MVE: Market value of equity (closing price $\mathrm{x}$ number of shares outstanding)

Debt: Total debt (current liabilities - current assets + long-term debt

TA: book value of total assets

\subsubsection{Independent Variable}

\section{a) Family Ownership}

Measurement of family ownership in this research uses dummy variables. Value 1 if family ownership has a total share of $10 \%$ or one family and / or company founder occupies a position as a board of commissioners or board of directors. Value 0 if otherwise.

b) Earning Management

Measurement of earnings management in this research uses discretionary accruals. Using discretionary accruals as a proxy for earnings management is calculated using the Modified Jones Model. The formula for calculating discretionary accruals used as a proxy for earnings management is as follows:

$$
D A_{i t}=\frac{T A_{i t}}{A_{i t-1}}-N D A_{i t}
$$


Information:

$D A_{i t}=$ Discretionary Accrual of company $\mathrm{i}$ in period $\mathrm{t}$

$N D A_{i t}=$ Non discretionary Accrual of company $\mathrm{i}$ in period $\mathrm{t}$

$T A_{i t}=$ Total Accruals of company $\mathrm{i}$ in period $\mathrm{t}$

$A_{i t-1}=$ Total Assets of company $\mathrm{i}$ in period $\mathrm{t}-1$

c) Ethnic diversity

This research uses the Blau Index to measure ethnic diversity. Blau Index is formulated as follows:

$$
B I=1-\sum p i^{2}
$$

Pi value is obtained by using the formula:

$$
P i=\frac{n_{i}}{N}
$$

Information:

BI: Blau Index

Pi: Proportion of group members in each of the four ethnic groups (Indonesian, Chinese, Indian and foreign)

$\mathrm{N}$ : Total ethnicity of all population

$\mathrm{Ni}$ : amount of ethnic on population to-i

\subsubsection{Control Variable}

a) Size Of firm

The size of firm in this research was measured by natural logarithms of the total book value of firm's assets. The formula for calculating firm size is as follows:

b) Age Of firm

$$
\text { Size }=\text { Ln Total Asset }
$$

Age firm can be measured by the following formula:

Age of Firm $=$ Years of observation- years of establishment of firm

c) Leverrage

The formula for calculating leverage is as follows:

d) Profitability

$$
\text { Lev }=\frac{\text { Total debt }}{\text { Total Asset }}
$$

The profitability ratio formula can be calculated by the formula:

$$
\text { ROA }=\frac{\text { Net Profit }}{\text { Total Asset }} \times 100
$$

\subsection{Population And Research Sample}

\begin{tabular}{|c|c|c|c|c|c|c|c|}
\hline No & Information & 2012 & 2013 & 2014 & 2015 & 2016 & 2017 \\
\hline 1. & $\begin{array}{l}\text { Mining companies listed on the Indonesia Stock Exchange } \\
\text { (IDX) }\end{array}$ & 37 & 37 & 38 & 39 & 39 & 41 \\
\hline \multirow[t]{2}{*}{2.} & Mining companies that suffer losses & 9 & 11 & 12 & 21 & 15 & 9 \\
\hline & Total & 28 & 26 & 26 & 18 & 24 & 32 \\
\hline
\end{tabular}

The population used in this research are mining companies listed on the Indonesian Stock Exchange (IDX) for the 2012-2017 period. The sampling technique used in this research is to use saturated sampling. The following is a sample of research that will be used in this research.

\begin{tabular}{|c|c|c|c|c|c|c|}
\hline & \multirow{2}{*}{ Model } & \multicolumn{2}{|c|}{ Unstandardized Coefficients } & \multirow{2}{*}{$\mathrm{T}$} & \multirow{2}{*}{ Sig. } & \multirow{2}{*}{ Infomation } \\
\hline & & B & Std. Error & & & \\
\hline \multirow{8}{*}{1} & (Constant) & 2,668 & 2,712 & 0,983 & 0,327 & \\
\hline & FO & $-0,244$ & 0,223 & 1,094 & 0,276 & Not Significant \\
\hline & $\mathrm{DA}$ & $-0,500$ & 0,314 & $-1,592$ & 0,114 & Not Significant \\
\hline & ETHNIC & $-0,668$ & 1,095 & 0,610 & 0,543 & Not Significant \\
\hline & SIZE & 0,043 & 0,082 & $-0,512$ & 0,603 & Not Significant \\
\hline & AGE & 0,003 & 0,007 & 0,353 & 0,725 & Not Significant \\
\hline & LEV & 0,383 & 0,425 & $-0,901$ & 0,369 & Not Significant \\
\hline & $\mathrm{ROA}$ & 0,038 & 0,012 & 3.327 & 0,001 & Significant 5\% \\
\hline
\end{tabular}

Table 2. Determination Sampel

\section{Results And Discussion}

Tabel 3. Test Results 


\subsection{Effect Of Family Ownership On Firm Value}

Based on statistical analysis the significance value of family ownership is 0.276 and this value is greater than $\alpha=$ 0.10 . The value of $\beta$ family ownership is -0.244 and is negative. Based on the results of these statistics, it can be concluded that family ownership does not affect to firm value. So H1 which said that family ownership has a positive effect on the firm value is rejected.

The results of this research are consistent with the research of L. Kalyanaraman (2015) which say that family ownership has no effect on firm value. Villalonga and Amit (2006) define family ownership as a company where the founder or family member becomes the director or blockholder of a company.

Therefore, the company stil to continue to increase the firm value even though the company is family ownership or non-family ownership. High of firm value is a desire for every company because high firm value reflects that the company is in good condition. If the firm's value is high, it will have an impact on the high price of the company's shares. High stock prices can attract investors to invest in these companies.

\subsection{Effect Of Erning Management On Firm Value}

Based on statistical analysis the significance value of earnings management is 0.114 and the value is greater than $\alpha=0.10$. $\beta$ value of -0.500 and negative value. Based on statistical results, it can be concluded that earnings management has no effect on firm value. So $\mathrm{H} 2$ which say earnings management negatively affects to the firm value is rejected.

The results of this research are consistent with research by Kamil and Hapsari (2014) which say that earnings management has no effect on firm value. One way to increase the firm of value is to do earnings management. Through earnings management practices, the company will present financial reports as best as possible so that the firm value can increase. However, earnings management practices can increase firm value on a small scale (Tandry et al., 2014). Therefore, the company still tries to increase the firm value even though the level of earnings management is high or low. For companies, the firm value is very important because with high firm value can improve the company's reputation among investors so that it can attract investors or prospective investors to buy shares of the company because the company's stock price is high.

\subsection{Effect Of Ethnic Diversity On firm value}

Based on the results of statistical analysis the significance value of ethnic diversity is 0.543 and the value is greater than $\alpha=0.10$. The value of $\beta$ ethnic diversity is $-0,668$ with a negative value. Based on these results, it can be concluded that ethnic diversity does not influence firm value. so $\mathrm{H} 3$ which say ethnic diversity has a positive effect on firm value is rejected.

The results of this research are suitable with (Jean et al., 2011) which shows that ethnic diversity has no effect on firm value. High firm value is the desire of every company owner. various efforts are made by company owners to improve the company. One factor that can affect the firm value is ethnic diversity. However, the company still tries to increase the firm value even though the level of ethnic diversity is high or low. So that ethnic diversity does not affect the firm value because the owner of the company wants the firm's value is high.

\section{Conclusion}

This research was conducted to prove empirically the influence of family ownership, earnings management and ethnic diversity on firm value. The results showed that family ownership, earnings management and ethnic diversity on firm value. The control variables in this research are size of fiem, age of firm and leverage do not affect the value firm value but profitability affects the firm value.

For the next research, researchers suggest to increase the research sample. Because the research sample in this research amounted to 154 but only 47 companies were categorized as family companies. So that with 47 companies can not be known the effect of family ownership on firm value. Therefore, for the next research, it can choose the population of research with more data in order to know the effect of family ownership on firm value.

\section{References}

Abdullah, Fahad, Shah, Attaullah, Gohar, Raheel, dan Iqbal, Abdullah Muhammad. (2011). The effect of group and family ownership on firm performance: Empirical evidence from Pakistan. International Review of Business Research Papers, 7, 4. July 2011 Pp. 2191-2208.

Awaworyi Churchill, S., Valenzuela, M. R., dan Sablah, W. (2017). Ethnic diversity and firm performance: Evidence from China's materials and industrial sectors. [Article]. Empirical Economics, 53(4), 1711-1731. doi: 10.1007/s00181-016-1174-5

Badrul Muttakin, Mohammad, Khan, Arifur, dan Subramaniam, Nava. (2014). Family firms, family generation and performance: evidence from an emerging economy. Journal of accounting in emerging economies, 4(2), 197-219.

Balakrishnan, Charumathi, dan Radha, Murali Krishnan. (2016). On the Determinants of Firm Value of Indian 
Companies.

Chung, H. M., dan Chan, S. T. (2012). Ownership structure, family leadership, and performance of affiliate firms in large family business groups. [Article]. Asia Pacific Journal of Management, 29(2), 303-329. doi: 10.1007/s10490-011-9281-5

De Jong, Abe, Mertens, Gerard, van der Poel, Marieke, dan van Dijk, Ronald. (2014). How does earnings management influence investor's perceptions of firm value? Survey evidence from financial analysts. Review of Accounting Studies, 19(2), 606-627.

Foerster, Stephen R, Sapp, Stephen G, dan Shi, Yaqi. (2009). The impact of management earnings forecasts on firm risk and firm value. AAA 2010 Financial Accounting and Reporting Section (FARS) Paper.

Gul, Ferdinand A, dan Zhang, Liang. (2016). Ethnicity, politics and firm performance: Evidence from Malaysia. Pacific-Basin Finance Journal, 40, 115-129.

Gyapong, Ernest, Monem, Reza M, dan Hu, Fang. (2016). Do women and ethnic minority directors influence firm value? Evidence from post-apartheid South Africa. Journal of Business Finance \& Accounting, 43(3-4), 370413.

Helmayunita, Nayang, dan Sari, Vita Fitria. (2013). Pengaruh Manajemen Laba dan Struktur Kepemilikan Perusahaan Terhadap Nilai Perusahaan. Wahana Riset Akuntansi, 1(1).

Herman, Muhammad Barru, dan Purwanto, Agus. (2014). Pengaruh Manajemen Laba, Risiko Pasar, Komite Audit, Audit Eksternal dan Struktur Kepemilikan terhadap Nilai Pasar (Studi Empiris Pada Perusahaan Manufaktur yang Terdaftar di Bursa Efek Indonesia Tahun 2011-2013). Journal of Accounting, 4(1), 1-12.

Jean, Ruey-Jer Bryan, Tan, Danchi, dan Sinkovics, Rudolf R. (2011). Ethnic ties, location choice, and firm performance in foreign direct investment: A study of Taiwanese business groups FDI in China. International Business Review, 20(6), 627-635.

Jensen, Michael C. (1994). Self interest, altruism, incentives, and agency theory.

Jensen, Michael C, dan Meckling, William H. (1976). Theory of the firm: Managerial behavior, agency costs and ownership structure. Journal of Financial Economics, 3(4), 305-360.

Juniarti. (2015). The negative impact of family ownership structure on firm value in the context of Indonesia. International Journal of Business and Globalisation, 15(4), 446-460.

Kalyanaraman, L. (2015). Do family ceos impact firm value? An empirical analysis of indian family firms. [Article]. Corporate Board: Role, Duties and Composition, 11(1), 62-73.

Kamil, Fauzan, dan Hapsari, Dini Wahyu. (2014). Pengaruh manajemen laba terhadap nilai perusahaan dengan mekanisme corporate governance sebagai variabel pemoderasi. eProceedings of Management, 1(3).

Klein, Peter, Shapiro, Daniel, dan Young, Jeffrey. (2005). Corporate governance, family ownership and firm value: the Canadian evidence. Corporate Governance: An International Review, 13(6), 769-784.

Madhogarhia, Pawan, Sutton, Ninon K, dan Kohers, Theodor. (2009). Earnings management practices among growth and value firms. Applied Financial Economics, 19(22), 1767-1778.

Nathan, Max. (2016). Ethnic diversity and business performance: Which firms? Which cities? Environment and Planning A: Economy and Space, 48(12), 2462-2483.

Nurhayati, Mafizatun. (2013). Profitabilitas, Likuiditas dan Ukuran Perusahaan Pengaruhnya Terhadap Kebijakan Dividen dan Nilai Perusahaan Sektor Non Jasa. Jurnal Keuangan \& Bisnis Program Studi Magister Manajemen Sekolah Tinggi Ilmu Ekonomi Harapan, 5(2), 144-153.

Shukeri, Siti Norwahida, Shin, Ong Wei, dan Shaari, Mohd Shahidan. (2012). Does board of director's characteristics affect firm performance? Evidence from Malaysian public listed companies. International Business Research, 5(9), 120.

Shyu, Jonchi. (2011). Family ownership and firm performance: evidence from Taiwanese firms. International Journal of Managerial Finance, 7(4), 397-411.

Suffian, Mohd, Taufik, Mohd, Mohd Sanusi, Zuraidah, dan Mastuki, Nor'azam. (2015). Real earnings management and firm value: Empirical evidence from Malaysia/Mohd Taufik Mohd Suffian, Zuraidah Mohd Sanusi and Nor'Azam Mastuki. Malaysian Accounting Review, 14(1), 26-47.

Tandry, Agatha Yosephine, Setiawati, Lulu, dan Setiawan, Evelyn. (2014). The effect of CSR disclosure to firm value with earning management as moderating variable: case study of non-financing firms listed at Indonesia Stock Exchange. International Journal of Trade and Global Markets, 7(3), 190-204.

Villalonga, Belen, dan Amit, Raphael. (2006). How do family ownership, control and management affect firm value? Journal of Financial Economics, 80(2), 385-417.

Yorke, Sally M, Amidu, Mohammed, dan Agyemin-Boateng, Cletus. (2016). The effects of earnings management and corporate tax avoidance on firm value. International Journal of Management Practice, 9(2), 112-131. 